\title{
Comparative Analysis of Fermented Milk Products with and without Added Vegetable Ingredients
}

\author{
Mihaela-Adriana TIȚA ${ }^{1 *}$, Adriana BÂRC $\breve{A}^{2}$ \\ ${ }^{1}$ Department of Agricultural Sciences and Food Engineering, Faculty of Agricultural Sciences, Food \\ Industry and Environmental Protection Lucian Blaga University of Sibiu \\ ${ }^{2}$ Department of Food Products Technology, Faculty of Food Technology, Technical University of Moldova \\ (Chişinău) \\ *Corresponding author, e-mail: mihaela.tita@ulbsibiu.ro
}

Bulletin UASVM Animal Science and Biotechnologies 74(2)/ 2017

Print ISSN 1843-5262; Electronic ISSN 1843-536X

DOI:10.15835/buasvmcn-asb: 0007

\begin{abstract}
In this study we wanted to obtain a fermented milk product from the kefir assortment with added chanterelle which are native mushrooms, because in our country is not such a product. We chose these mushrooms for their rich composition in essential amino acids, vitamins and mineral salts and which in turn are very consumed. The resulting product shows a high nutritional value and antioxidant properties due to the valuable compounds in the mushroom composition. The mushrooms were previously lyophilized and the resulting powder was added in different proportions, obtaining three samples. These samples were compared with a blank sample over a 12 days period by sensory and physicochemical point of view.
\end{abstract}

Keywords: fermented milk, kefir, mushrooms, nutritional value

\section{INTRODUCTION}

Kefir is a fermented milk product produced for hundreds of years in the Caucasus Mountains, traditional in leather bellows, oak barrels or clay pots and very consumed in our country due to its nutritional and therapeutic value. (Costin, 2005). Traditional kefir is known in various countries and under other names: Kefyr, Kephir, Kefer, Kiaphur, Keppi, and Kippi. This fermented milk product is the result of a double lactic and alcoholic fermentation (Georgescu, 2005), it is relatively sour, it is a distinct taste of yeast taste and a sparkling structure determined by the presence of carbon dioxide. All of these characteristics are given by the kefir granules which represent a complex of microorganisms consisting of the association of about 30 bacteria and yeasts. Kefir has a higher content than milk in vitamin B1, B2 and folic acid. In various studies have been investigated some effects of kefir consumption, such as antibacterial effects (Zacconi et al., 1995), immunological
(Furukawa, et al., 1991), hypocholesterolemic (Tamai et al., 1996) and digestive. Chanterelle (Cantharellus cibarius) are native mushrooms that are studied for their benefits (Locsmánd et al., 2013). It is known to the people as the yellow sponge and marigold. The sponge grows in Romania, Bessarabia and Northern Bucovina in deciduous forests (under beech, oak), such as conifers, often on mussels and among blueberries, or by bushes of raspberries and blackberries from May to October (November). It consists of the hat: it is $3-8 \mathrm{~cm}$ in diameter, it is smooth and yellowishfree, as in the orange or white sponge variations; leg: it is 3-8 (10) cm in height and 0.7-2 cm thick, the same color as the hat, is robust, hard, smooth, in the shape of a truncated cone; meat: it is hard, fibrous, generally yellowish white with a slightly peppery taste but pleasant and smell a little peach and apricot. Vegetable protein obtained from mushrooms ranks second, world wide after soybean. The edible mushrooms in general are 
considered foods of high nutritional value. The edible part of a mushroom represents more than $3 / 4$ of the product used by the consumer. The chemical composition of mushrooms differs from one species to another, depending on the stage of development, the nutrient substrate which they grow, the morphological aspect taken into account, the growth period, the microclimate conditions, etc. Chanterelle are rich in vitamin B1 (important for the nervous system and heart), vitamin B6 (supports the immune system and regulates the level of blood sugar), vitamin B9 (essential for proper liver function), vitamin B12 (important in the functioning of the nervous system) , fiber (stimulates digestion), potassium (maintains cardiovascular health), zinc (supports the immune system), copper (an essential mineral in the growth process). They also contain vitamins $\mathrm{A}$ and $\mathrm{D}$ as well as essential amino acids. Glutamic acid is also found in chanterelle mushrooms, and there are reasons to believe it helps to strengthen the immune system and fight against cancer, infections and arthritis.

\section{MATERIALS AND METHODS}

For this study we used cow's milk from a private farm, kefir grains and chanterelle. First we analyzed raw milk from a physicochemical and microbial point of view. The most relevant analysis to see its quality was the blue reductase test, which confirmed our microbiological quality. It allows to indirectly determine the degree of contamination by measuring the milk-reducing activity caused by the presence of bacteria. The result will influence the heat treatment used. Cantharella cibarius was harvested in September from the mountainous area of Paltinis Resort, which is located in the middle of the Cindrel Mountains conifer forest.I made three samples of kefir with different addition of Cantharellus cibarius which were previously washed, cut and lyophilized with the lyophilizer ALPHA 1-4 Ldplus ( is a powerful laboratory and preproduction tool for lyophilizing solid or liquid products in ampoules, glass vessels, plasma bottles; condensing capacity $4 \mathrm{~kg}$, temperature -550C ). The samples contain $250 \mathrm{ml}$ of sown milk and have been noted: CG1 - it contains an addition of 10 grams of chanterelle, CG2 - it contains an addition of 15 grams of chanterelle, CG3 - it contains an addition of 20 grams of chanterelle. The proportions of Cantharella cibarius are different to see how it influences the consistency of the finished product.We also did the blank sample to compare the results, a simple kefir containing milk and kefir granulated noted with CS. These samples were analyzed (Savu et.al.1997) over a period of 12 days (this period was chosen to see how it behaved the product and to obtain a lower shelf life than the shelf life of the products on the market) from the point of view:

- Sensory - method by comparison with scoring ranges - the evaluation of each organoleptic characteristic is compared with a scale of 0 to 5 points;

- Physicochemical:

- determination of acidity by titration with $\mathrm{NaOH}$ in the presence of phenolphthalein, the result is expressed in degrees Thorner;

- determination of lactose - polarimetric method II using the polarimeter P8000-Kruss Optronic where the polarimetry is made in a $20 \mathrm{~mm}$ tube at $20^{\circ} \mathrm{C}$ and the result is expressed in $\%$;

- determination of $\mathrm{CO}_{2}$ content from fermented milk products where the amount of carbon dioxide is expressed by the number of centimeters with which the coat was placed in a tube and kept at a certain temperature (Tita, 2002);

- determination of $\mathrm{pH}$ with $\mathrm{pH}$-meter Orion 2Star -ThermoElectron.

\section{RESULTS AND DISCUSSIONS}

a.Sensory analysis:

After sensory analysis (which was made by 15 consumers of fermented milk products - I chose consumers and not authorized wine tasting to see the way of perceiving new products) were obtained the following results for the analyzed samples presented in figure no.1:

From the graphical presentation we can see that the highest score for all sensory characteristics was obtained by sample CG2, which means that it has the optimal content of mushrooms.

\section{b.Determination of acidity:}

The results obtained in acidity determination are shown in the next figure:

From the presented results, it is observed that for all four samples analyzed the acidity increased 


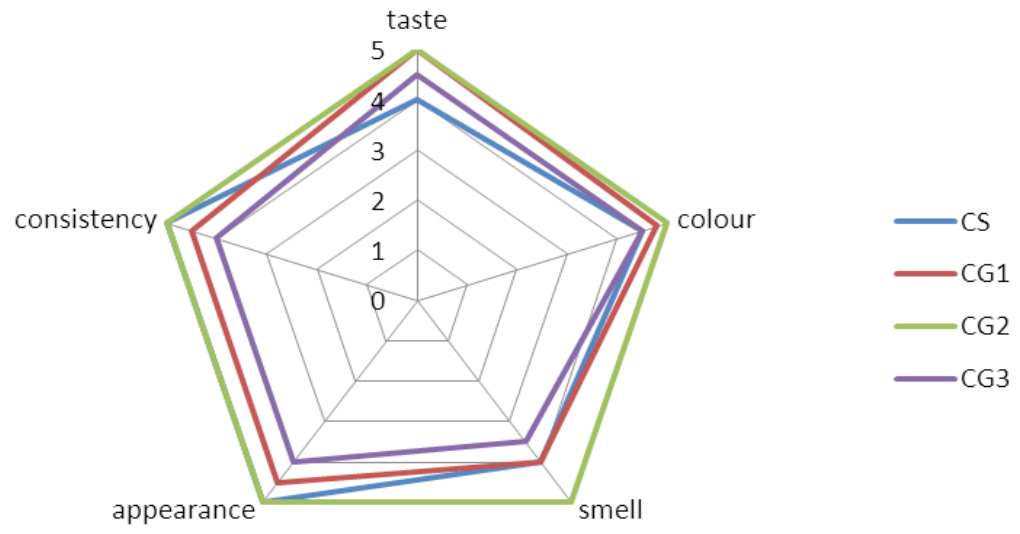

Fig. 1. Sensory analysis

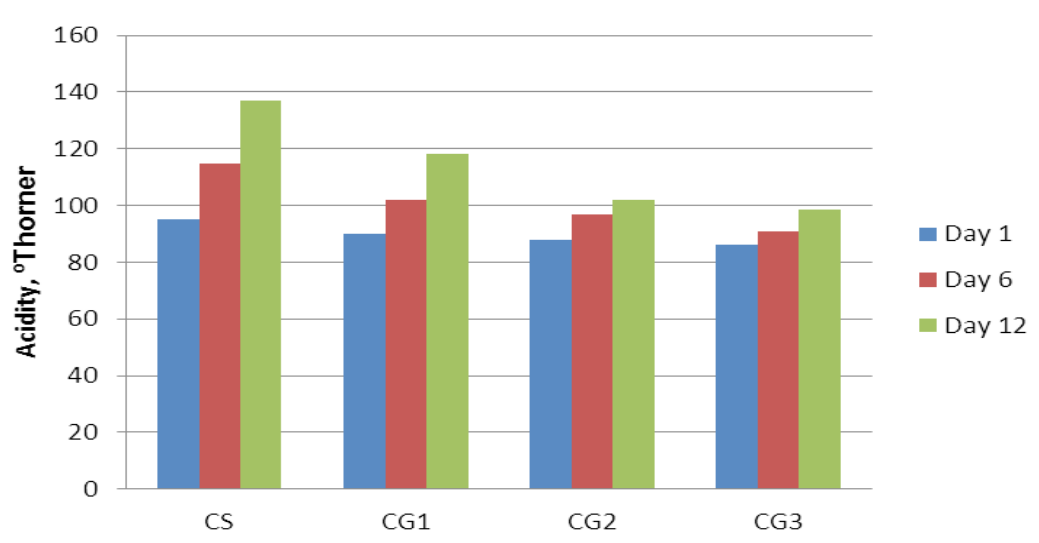

Fig. 2. The evolution of acidity

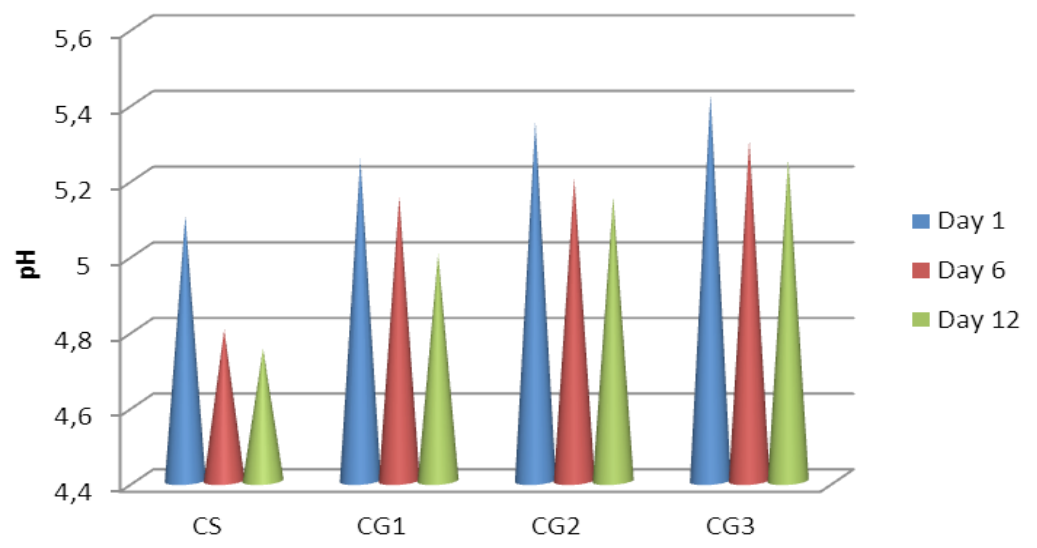

Fig. 3. The evolution of $\mathrm{pH}$

during the 12 days, the highest value of acidity has the blank sample, and the lowest value has sample CG3, because as the addition of mushrooms is higher, the intensity of the lactic fermentation decreases.

\section{c.Determination of $\mathrm{pH}$ :}

The results obtained in $\mathrm{pH}$ determination are shown in Figure 3:
The results show that with the accumulation of lactic acid in the analyzed samples it decreases the $\mathrm{pH}$ value, respectively the blank sample has the lowest $\mathrm{pH}$ value over the analyzed period.

\section{d.Determination of lactose:}

After analyzes were obtain the following results which are presented in the next figure: 


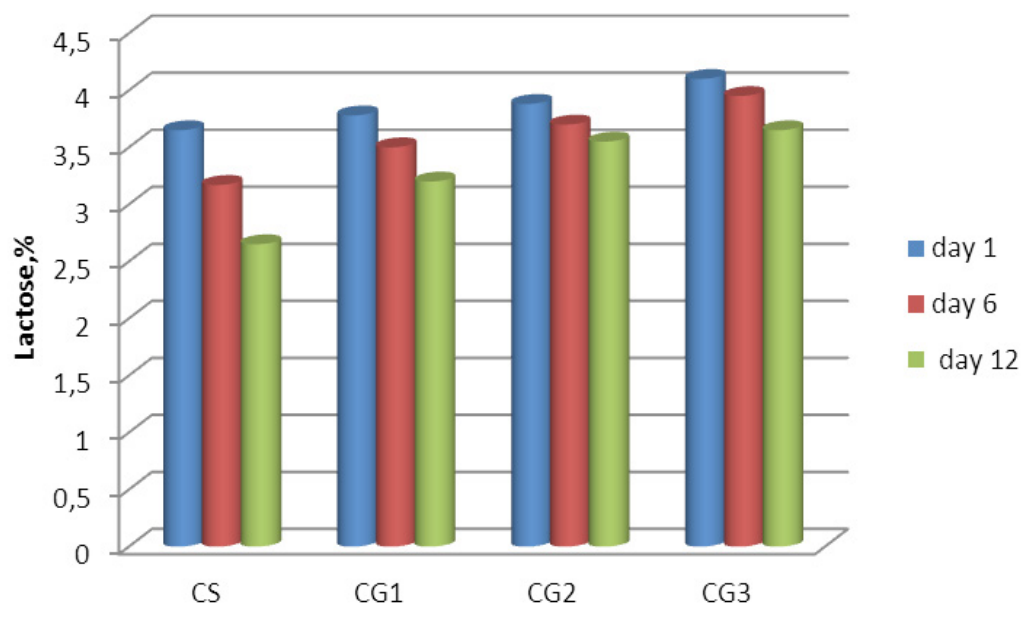

Fig. 4. The evolution of lactose

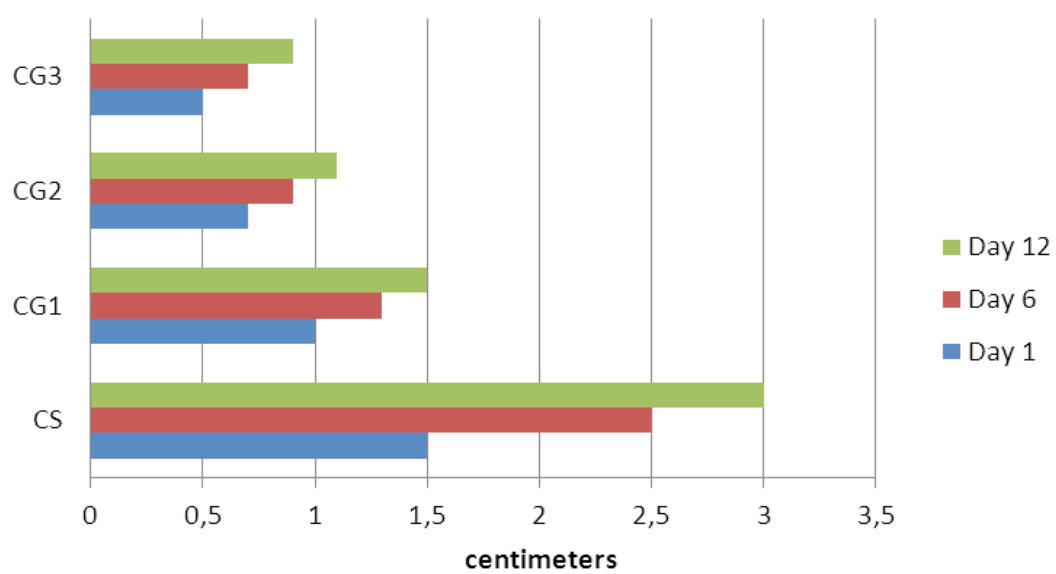

Fig. 5. The evolution of $\mathrm{CO}_{2}$

Graphical representation shows a decrease in lactose content for all analyzed samples, which is correlated with the intensity of lactic fermentation, due to the accumulation of lactic acid resulting from the action of lactic bacteria on lactose. Simple kefir has a much lower amount of lactose since the first day because lactic fermentation is much more intense compared to the samples with chanterelle addition

\section{e. The amount of $\mathrm{CO}_{2}$ :}

The results obtained during the analyzed period are presented in figure no.5:

The amount of $\mathrm{CO}_{2}$ increases in the four samples due to alcoholic fermentation that is specific to kefir, given by the activity of the yeast found in the kefir granule composition. The highest $\mathrm{CO}_{2}$ content is in the blank sample, and the lowest in the CG3 sample. Carbon dioxide is desirable in these types of fermented milk products because it has a positive influence on the taste that confers a specific flavor profile and contributes to so-called freshness.

\section{CONCLUSION}

Following the analysis of the four samples of kefir was found that in the sensory analysis the CG2 sample obtained the highest scores for all sensory characteristics, which means that it has the optimal content of chanterelle addition. At the physicochemical analysis, the blank sample showed the highest values for all the analyzes performed, because the fermentation processes are more extensive comparative to the samples to which different amounts of chanterelle have been added. This product will continue their studies in order to determine the nutritional value and determination of rheological properties. 


\section{REFERENCES}

1. Costin GM (2005). Produse lactate fermentate, Editura, Academia, Galati, p.161-165;

2. Locsmándi C, Vasas G (2013). Ghidul culegătorului de ciuperci. Editura Casa, Cluj-Napoca, p.92-94;

3. Furukawa N, Matsuaka T, Takahashi YY (1991). Effects of fermented milk on the delayed-type hypersensitivity reponse and survinal day in mice bearing Meth-A.Anim. Sci. Tec.62,579-585;

4. Georgescu Ghe, Banu C, Mărginean Gh, Păsat GhD, Dorin S (2005). Cartea producatorului si procesatorului de lapte, vol.4, Cunoașterea și procesarea laptelui, Ed. Ceres, București, p. 334-335;
5. Savu C, Mihai G (1997). Controlul sanitar veterinar al alimentelor. Editura Ceres, Bucuresti, p.177-178;

6. Tamai Y, Yashimitsu N, Watanabe Y, Kuwabara Y, Nagai S (1996). Effects of milk fermented by culturing with various lactic acid bacteria and a yeast on serum cholesterol level in rats, J.Ferment Bioeng.81,181-182;

7. Tita MA (2002).Manualul de analiză si controlul calitatii în industria laptelui.Sibiu: Ed. Univ. L. Blaga.p.204-205.

8. Zacconi C, Parisi MG, Sarra PG, Dallavalle P, Battazzi V (1995). Competitive exclusion of Salmonella kedougou. In kefir fed chicks. Microbiolo.Alim.Nutr.12, 387-380. 